\title{
Atractilina alinae sp. nov. and Neosporidesmium vietnamense sp. nov. - two new synnematous hyphomycetes from Vietnam
}

\section{Vadim A. Mel'nik ${ }^{1 *} \&$ Uwe Braun ${ }^{2}$}

${ }^{1}$ Laboratory of the Systematics and Geography of Fungi, Komarov Botanical Institute, Russian Academy of Sciences, Professor Popov Street 2, St. Petersburg 197376, Russia

${ }^{2}$ Martin-Luther-Universität, Institut für Biologie, Bereich Geobotanik und Botanischer Garten, Herbarium, Neuwerk 21, 06099 Halle (Saale), Germany

Received 26 September 2013 / Accepted 21 October 2013 / Published 3 November 2013

Mel'nik, V.A. \& Braun, U. 2013. Atractilina alinae sp. nov. and Neosporidesmium vietnamense sp. nov. - two new synnematous hyphomycetes from Vietnam. - Mycobiota 3: 1-9. doi: 10.12664/mycobiota.2013.03.01

\begin{abstract}
The new species Atractilina alinae and Neosporidesmium vietnamense, collected in Vietnam on fallen leaves of an unidentified tree and on bark of a twig of an unknown tree, respectively, are described, illustrated and discussed. $A$. alinae resembles the hyperparasitic $A$. parasitica, but differs in having quite distinct conidia. Neosporidesmium vietnamense is morphologically unique by its synnematous, indeterminate conidiomata, integrated, terminal, monoblastic, non-proliferating conidiogenous cells and obclavate, rostrate, euseptate conidia, but taxonomically rather complex with regard to its generic affinity.
\end{abstract}

Key words: Ascomycota, asexual morphs, new species, Southeast Asia, synnemata, Vietnam

\section{Introduction}

Numerous specimens of fungi have been collected within the scope of a research program of the Vietnam-Russian Tropical Research and Technological Centre. In a series of papers, Mel'nik (2011, 2012a, b) and Mel'nik et al. (2012, 2013) published results of examinations of several Vietnamese hyphomycetes, including numerous new records and some new species. Additional collections found on fallen leaves and on bark of a twig of unidentified trees turned out to be new species of Atractilina Dearn. \& Barthol. and Neosporidesmium

\footnotetext{
*Corresponding author: e-mail: melnik@mail.ru
} 
Mercado \& J. Mena, respectively. Attempts to cultivate these fungi, in order to be able to carry out molecular sequence analyses, failed. However, these fungi are morphologically easily distinguishable from all other species of Atractilina and Neosporidesmium and are hence described as new species.

\section{Materials and methods}

Fresh samples collected in the course of field trips in Vietnam were dried at room temperature. The collections were later examined in distilled water and photographed using a Zeiss microscope, Stemi 2000CS, and Axio Imager A1 equipped with Nomarski differential interference contrast optics. The identification of the new species was accomplished through comparison with descriptions of other species hitherto assigned to Atractilina and Neosporidesmium.

\section{Taxonomic treatment}

Atractilina alinae Melnik \& U. Braun, sp. nov.

Fig. 1

MycoBank, MB 805921

Atractilinae parasiticae similis, sed conidiis brevioribus, (20-)30-35(-40) $\mu \mathrm{m}$, (3-)4-7-septatis, hyalinis vel dilute flavido-viridulis, levibus, non rostratis, apice non inflato, non hyperparasiticis.

Conidiomata synnematous on the natural substrate, solitary, scattered, dark brown to blackish. Synnemata determinate, up to $500 \mu \mathrm{m}$ long, composed of a firm, brown, subcylindrical stalk, $10-25 \mu \mathrm{m}$ wide, base often somewhat wider, up to $30 \mu \mathrm{m}$, and a rather compact, paler head, subglobose in outline, up to $80 \mu \mathrm{m}$ diam., individual appressed filaments of the stalk 1.5-4 $\mu \mathrm{m}$ wide, pigmented, septate throughout, wall smooth, thin to slightly thickened, filaments apically slightly to moderately splaying out, occasionally branched, free part up to $45 \mu \mathrm{m}$ long and 2.5-5 $\mu \mathrm{m}$ wide, pale to medium brown, tips often paler; conidiogenous cells integrated, terminal, up to $35 \mu \mathrm{m}$ long, polyblastic, with a single or several distinct denticles, proliferation sympodial; denticles subcylindrical to usually conical, $1-2 \times 0.8-1.5 \mu \mathrm{m}$, apex truncate, thin-walled. Conidia formed singly, broadly fusiform, ellipsoid, attenuated towards base and apex, (20-)30-35(-40) $\times(3-) 4-7$ $\mu \mathrm{m},(2-) 4-7$-septate, septa thin and rather inconspicuous, subhyaline to faintly yellowish green, thin-walled, smooth or almost so, apex subobtuse to pointed, base obconically truncate, hila $1-1.5 \mu \mathrm{m}$ wide, neither thickened nor darkened or only slightly darkened by being refractive.

Type on decaying leaves of an unidentified tree: Vietnam, Dong Nai Prov., Cat Tien National Park, Nam Cat Tien Sector, right bank of the river Dong Nai, polydominant monsoon lowland tropical forest, near the climatological tower, $11^{\circ} 26^{\prime} 25^{\prime \prime} \mathrm{N}, 107^{\circ} 23^{\prime} 59^{\prime \prime} \mathrm{E}$, 22 Nov 2012, Yu. Novozhilov (holotype, HAL 2605 F; isotype, LE 263984).

Etymology: dedicated to Alina V. Alexandrova for her contribution to the knowledge of Vietnamese fungi. 

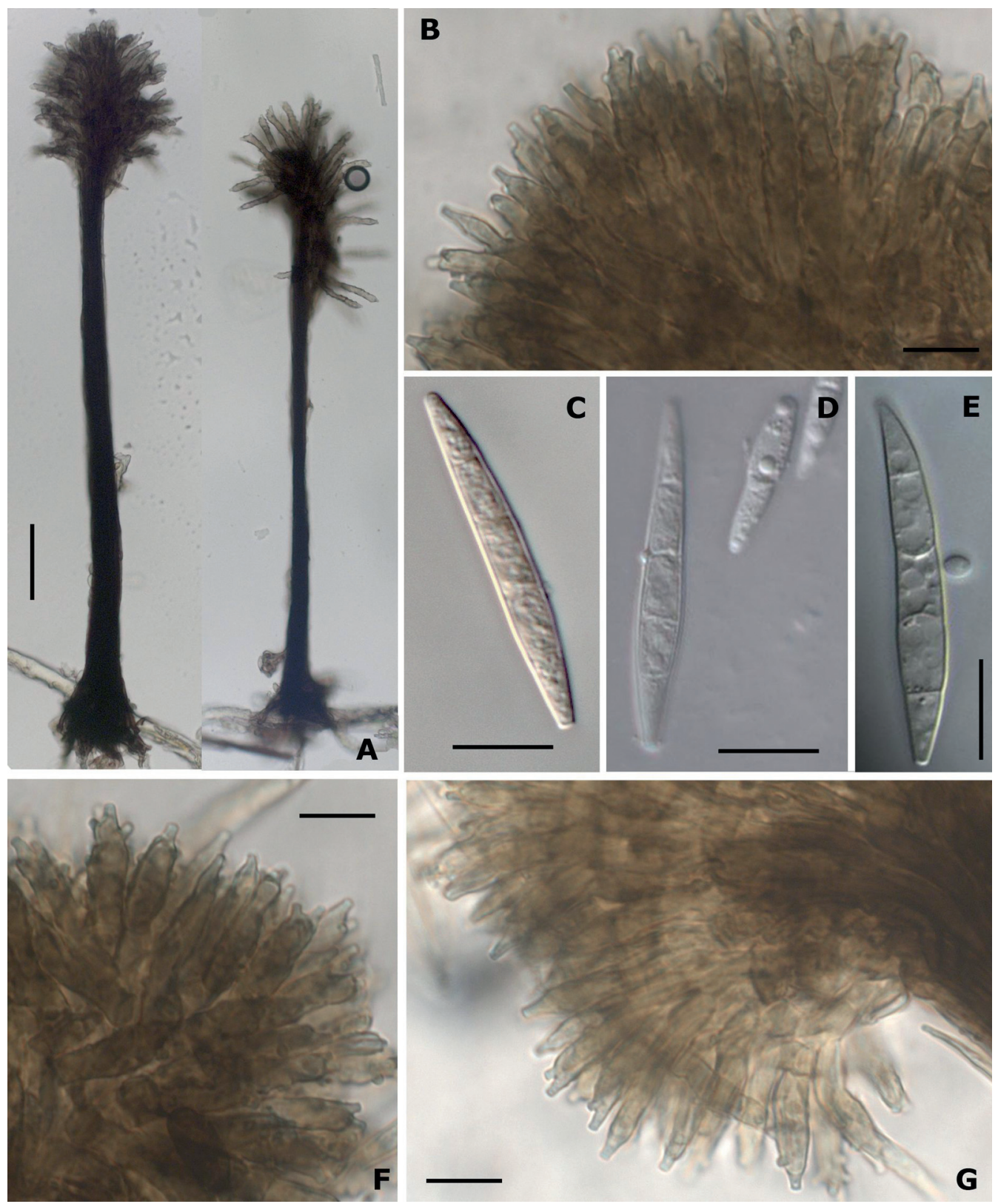

Fig. 1. Atractilina alinae, micrographs (based on type material), A - synnemata, B, F, G conidiogenous cells, C, D, E - conidia. Scale bars: A $=50 \mu \mathrm{m}$ and B-G $=10 \mu \mathrm{m}$ 
Neosporidesmium vietnamense Melnik \& U. Braun, sp. nov.

MycoBank, MB 805922

Neosporidesmii micheliae similis, sed synnematibus longioribus, (380-)500-1430 $\mathrm{mm}$, et latioribus, ad basim 40-45 $\mu \mathrm{m}$, conidiophoris angustioribus, 2-2.5 $\mu \mathrm{m}$ latis et conidiis longioribus et latioribus, (75-)80-96(-110) × 11-13.5 $\mu \mathrm{m}$, laevibus, verrucosis vel pagina inaequali, apice subhyalino.

Conidiomata synnematous on the natural substrate, on bark, solitary, scattered, dark brown to blackish. Synnemata indeterminate, erect, straight, (380-)500-1430 $\mu \mathrm{m}$ high, stem somewhat decreasing in width from base to top, $40-45 \mu \mathrm{m}$ wide at the base and $18-20 \mu \mathrm{m}$ in the apical portion, composed of parallel, tightly appressed, dark brown, smooth, septate, thin-walled threads (conidiophores), 2-2.5 $\mu \mathrm{m}$ wide, without distinct head, diverging terminally and laterally, splaying out portions mainly consisting of terminal conidiogenous cells, fertile zone covering the upper quarter to third of the synnemata. Conidiogenous cells integrated, terminal, monoblastic, determinate, doliiform to lageniform, usually somewhat curved, 9-11 $\times 5-7.2 \mu \mathrm{m}$, wall dark brown, thin to somewhat thickened, smooth, conidiogenous locus at the truncate apex, 4-4.5 $\mu \mathrm{m}$ wide, unthickened, concolorous with the lateral wall. Conidia solitary, formation holoblastic, dry, obclavate, gradually tapering towards the apex, rostrate, base obconically truncate, (75-)80-96(-110) × 11-13.5 $\mu \mathrm{m}, 9-12$-euseptate, not constricted at the septa, cells often with distinct lumen, pale brown, paler at the apex, subhyaline, wall thin to somewhat thickened, smooth to somewhat rough, surface at least not quite even, hila 3-4 $\mu$ m wide, unthickend and not darkened.

Type on bark of a dry, thin branch of an unidentified tree: Vietnam, Dong Nai Prov., Cat Tien National Park, Nam Cat Tien Sector, Ma Da, near a small bridge close to Memorial of Defenders, monsoon tropical forest with prevalence of lianas and palms (Calamus spp.), $11^{\circ} 23^{\prime} 02^{\prime \prime} \mathrm{N}, 107^{\circ} 03^{\prime} 40^{\prime \prime} \mathrm{E}, 11 \mathrm{Jan} 2011$, leg. Yu. Novozhilov (holotype, DAOM 242720; isotype, LE 263986).

\section{Discussion}

Due to the formation of true synnemata, denticulate conidiogenous cells and pale pluriseptate conidia, the Vietnamese hyphomycete, collected on fallen leaves of an unidentified tree species, may easily be identified as member of Atractilina (Deighton \& Pirozynski 1972; Ellis 1976; Seifert et al. 2011). Only a few species have been assigned to this genus, including some non-synnematous species which are probably not congeneric. Deighton \& Pirozynski (1972) introduced the combination Atractilina asterinae (Hansf.) Deighton \& Piroz. for a species hyperparasitic on sooty molds in Africa. This species is non-synnematous, i.e. it forms solitary conidiophores, and the conidia are distoseptate. Therefore, it is very doubtful if this species has been correctly assigned to Atractilina. A. hymenaeae Bat. \& J.L. Bezerra (Batista et al. 1961), described from Brazil on Hymenaea sp., associated with Asterina and Asteridiella spp., is also non-synnematous and very probably not correctly placed in Atractilina. A. alinae roughly resembles A. parasitica (G. Winter) Deighton \& Piroz. (Deighton \& Pirozynski 1972; Ellis 1976), a hyperparasitic species 

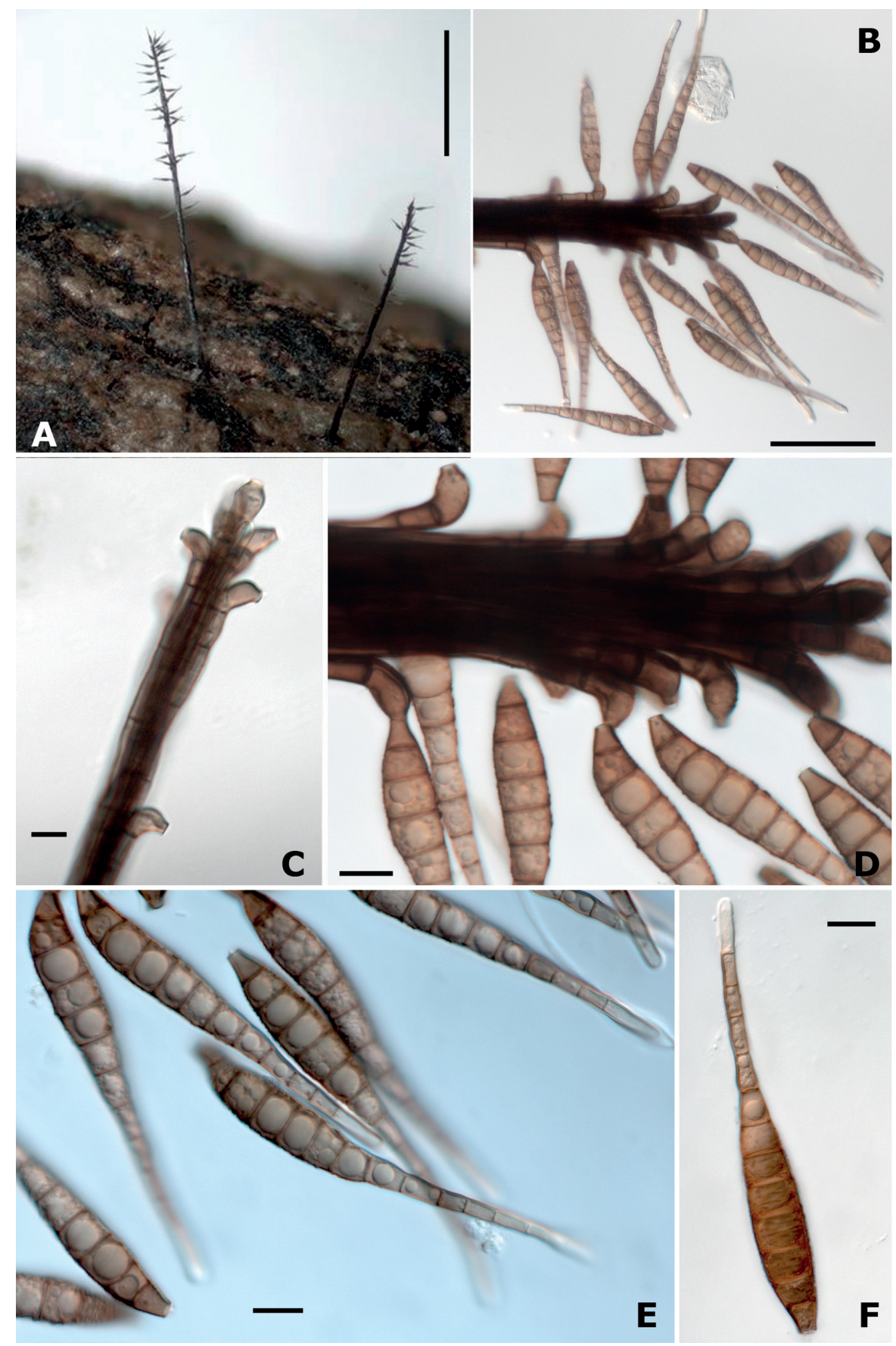

Fig. 2. Neosporidesmium vietnamense, micrographs (based on type material), A - synnemata, B-D - apex of synnema with conidiogenous cells (B and D in addition with conidia), E-F - conidia. Scale bars: A $=500 \mu \mathrm{m}, \mathrm{B}-\mathrm{F}=10 \mu \mathrm{m}$ 
widespread in tropical countries, but the latter species has quite distinct conidia which are longer, 35-50 $\mu \mathrm{m}$, mostly 3-septate, often minutely verruculose and slightly pigmented with age, frequently with beak-like apex and a terminal small knob. The synnemata are up to $1.5 \mathrm{~mm}$ long and $40 \mu \mathrm{m}$ wide. A. calycini Jana, A.K. Das \& S.N. Ghosh (Jana et al. 2006), described from India on living leaves of Neurocalyx calycinus, is morphologically very close to $A$. parasitica and said to be distinguished by shorter synnemata, up to 900 $\mu \mathrm{m}$, occasionally branched conidiophores wider near the apex, and smaller, always smooth conidia without terminal knob. The ecology of this species is unclear and not properly specified. In the description, $A$. calycini is classified to be hyperparasitic, but its mycelium is described to grow superficially on living leaves. Other fungi on the host on which this species might be developed as hyperparasite are not mentioned. A. biseptata R.F. Castañeda (Castañeda-Ruiz 1986) is a true synnematous Atractilina species, but differs from the Vietnamese fungus in having consistently 2 -septate conidia.

The generic affinity of the new species tentatively assigned to the genus Neosporidesmium (Mercado \& Mena 1988) is rather complex and needs to be discussed in detail. This fungus is well-characterized by forming synnematous indeterminate conidiomata with integrated, terminal, monoblastic, non-proliferating conidiogenous cells and obclavate, rostrate, euseptate conidia formed singly. Based on these traits, this fungus is easily referable to a complex of synnematous genera around Morrisiella Saikia \& A.K. Sarbhoy (= Hemisynnema Subram.), Neosporidesmium, Novozymia W.P. Wu, Podosporium Schwein, as well as Sporidesmina Subram. \& Bhat and may be considered a species of the Sporidesmium complex s. lat. (Wu \& Zhuang 2005; Seifert et al. 2011). However, using the key to Sporidesmium-like genera in Wu \& Zhuang (2005) and the general key to synnematous hyphomycete genera in Seifert et al. (2011), and the descriptions and illustrations in these works, no perfectly fitting genus has been found. Wu \& Zhuang (2005) recognized Morrisiella as genus of its own, and Hemisynnema was reduced to synonym with this genus. Furthermore, they considered Janetia synnematosa Sivan. \& W.H. Hsieh a synonym of Morrisiella indica Saikia \& A.K. Sarbhoy, the type species of Morrisiella. In contrast, Seifert et al. (2011) listed the latter genus as synonym of Janetia M.B. Ellis. The conidiogenous cells of $M$. indica and the new fungus from Vietnam are very similar, but Morrisiella differs in having laterally integrated, pleurogenous conidiogenous cells, and the conidia are distoseptate. The structure of the conidiogenous cells in Novozymia is also very similar, but they proliferate percurrently, leave distinct annellations, and the conidia are distoseptate. Podosporium is another superficially similar genus with euseptate conidia, but it can be readily ruled out due to its tretic conidiogenesis. Sporidesmina malabarica Subram. \& Bhat, the type species of Sporidesmina, has unique synnemata with a carbonaceous structure, characteristically crowded conidiogenous cells, and the conidia are eu- and distoseptate and form a terminal globose mucilaginous appendage. Last but not least, Neosporidesmium has to be taken into consideration. This genus was introduced for a synnematous species with monoblastic conidiogenous cells, percurrent proliferation resulting in a succession of swollen, almost monilioid cells, and solitary pluridistoseptate conidia (Mercado \& Mena 1988). Wu in Wu \& Zhuang (2005) described N. microsporum W.P. Wu, which is morphologically close to the type species of Neosporidesmium, and added the new species $N$. sinense W.P. Wu, a species with non-proliferating conidiogenous cells, 
leading to a significant widening of the generic circumscription of the latter genus. Additional species have been described in Ma et al. (2011), viz. the proliferating $N$. antidesmatis Jian Ma \& X.G. Zhang (as "antidesmae"), and the two non-proliferating taxa N. malloti Jian Ma \& X.G. Zhang and N. xanthophylli Jian Ma \& X.G. Zhang. A second significant widening of the generic concept of Neosporidesmium has been made by the description of $N$. micheliae Y.D. Zhang \& X.G. Zhang, a Chinese species characterized by having euseptate conidia (Zhang et al. 2011), which enables us to assign the new Vietnamese species to the latter genus. $N$. micheliae is quite distinct from $N$. vietnamense and easily distinguishable by having much shorter and narrower synnemata, up to $530 \mu \mathrm{m}$ long and 20-30 $\mu \mathrm{m}$ wide below, wider conidiophores, 4.5-6.5 $\mu \mathrm{m}$, as well as smooth, shorter and narrower conidia, 40-60 $\times 8.5-11 \mu \mathrm{m}$, with pale brown, non-rostrate apex. All other species of this genus differ in having distoseptate conidia. The only rational alternative to an inclusion in Neosporidesmium would be the introduction of a new genus for Neosporidesmium-like species distinguished by forming euseptate conidia, which would strictly follow the generic concept of Wu \& Zhuang (2005), who accepted Subramanian's (1992) splitting of the Sporidesmium Link s. lat. complex by keeping genera like Sporidesmium Link s. str. (euseptate conidia) and Ellisembia Subram. (distoseptate conidia) as separate taxa. However, the taxonomic relevance of conidial septation (eu- and distosepta) as well as the formation of mononematous versus synnematous formations of conidiophores within the Sporidesmium complex is quite unclear and not yet sufficiently phylogenetically proven. Shenoy et al. (2006) published results of comprehensive molecular sequence analyses of a wide range of taxa of the Sporidesmium complex suggesting that Sporidesmium, Ellisembia and other segregated genera are not monophyletic. Particular species of these genera are phylogenetically distributed in two major ascomycete classes, Dothideomycetes and Sordariomycetes. A single sequence referred to as Neosporidesmium sp. clustered in the Dothideomycetes adjacent to Sporidesmium australiense M.B. Ellis. Under these circumstances, it does not make any sense to add a further genus just based on a single morphological character.

The following key to species of Neosporidesmium is based on a key previously published by Ma et al. (2011), adapted and supplemented by inclusion of $N$. micheliae and $N$. vietnamense:

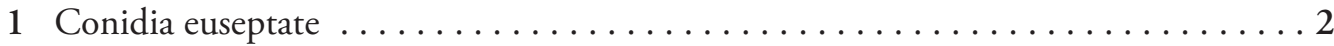

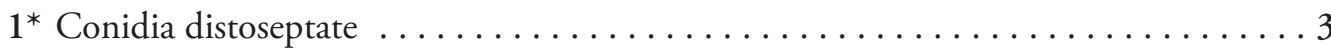

2 Synnemata (380-)500-1430 $\mu \mathrm{m}$ long, 40-45 $\mu \mathrm{m}$ wide below, conidiophores 2-2.5 $\mu \mathrm{m}$ wide, conidia $(75-) 80-96(-110) \times 11-13.5 \mu \mathrm{m}$, wall smooth to somewhat rough, surface at least not quite even, rostrate apex subhyaline . . . . . . vietnamense

2* Synnemata shorter, up to $530 \mu \mathrm{m}$ long, and narrower, 20-30 $\mu \mathrm{m}$ wide below, conidiophores wider, 4.5-6.5 $\mu \mathrm{m}$, conidia shorter and narrower, 40-60 $\times 8.5-11 \mu \mathrm{m}$, wall smooth, apex not distinctly rostrate and pale brown $\ldots \ldots \ldots \ldots$. micheliae

3 Conidiogenous cells percurrently proliferating $\ldots \ldots \ldots \ldots \ldots \ldots \ldots \ldots$

$3^{*}$ Conidiogenous cells monoblastic, determinate, without any proliferation . . . . . 6 
4 Conidia distinctly rostrate $\ldots \ldots \ldots \ldots \ldots \ldots \ldots \ldots \ldots \ldots \ldots \ldots$ antidesmatis

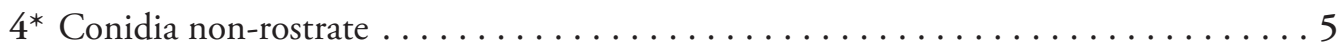

5 Conidia 45-67 $\times 6-7 \mu \mathrm{m}, 6-7$-distoseptate $\ldots \ldots \ldots \ldots \ldots \ldots . \ldots \ldots$. microsporum

5* Conidia much larger, 55-100 × 15-19 $\mu \mathrm{m}, 8-12$-distoseptate $\ldots \ldots . .$. . maestrense

6 Synnemata very broad, $80-110 \mu \mathrm{m}$ at the base, conidia very long, $120-150 \mu \mathrm{m}$, with

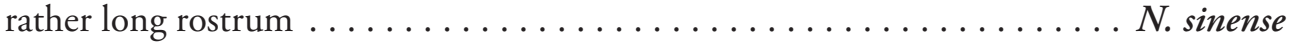

6* Synnemata much narrower, $20-55 \mu \mathrm{m}$ at the base, conidia much shorter, about $20-50$

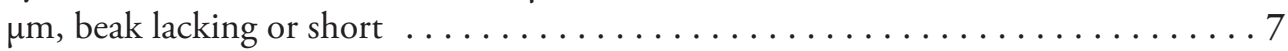

7 Conidia 22.5-33.5 $\times 7-9 \mu \mathrm{m}, 6-7$-distoseptate, apex pale brown and not distinctly rostrate ..................................................

$7^{*}$ Conidia somewhat longer and much broader, 33.5-51.5 × 12-14 $\mu \mathrm{m}, 6$-10-distoseptate, with distinct, hyaline or subhyaline rostrum, 11-19 $\mu \mathrm{m}$ long ..... N. xanthophylli

Acknowledgements. Sincere thanks are due to Yu. Novozhilov, who made the field collections in Vietnam and provided the material for further taxonomic treatment, and E. Popov for the final preparation and arrangement of the illustrations.

\section{References}

Batista, A.C., Bezerra, J.L. \& Peres, G.E.P. 1961. Nuovos ou raros Deuteromycetes. - Memórias da Sociedade Broteriana 14: 73-82.

Castañeda-Ruiz, R.F. 1986. Fungi Cubenses: 1-20.

Deighton, F.C. \& Pirozynski, K.A. 1972. Microfungi. V. More hyperparasitic hyphomycetes. - Mycological Papers 128: 1-110.

Ellis, M.B. 1976. More dematiaceous Hyphomycetes. CMI, Kew.

Jana, T.K., Das, A.K. \& Ghosh, S.N. 2006. Studies on foliicolous fungi - I. - Geobios (Jodhpur) 33(1): 9-16. Ma, J., Wang, Y., Ma, L.G., Zhang, Y.D., Castañeda-Ruiz, R.F. \& Zhang, X.G. 2011. Three new species of Neosporidesmium from Hainan. - Mycological Progress 10: 157-162. http://dx.doi.org/10.1007/ s11557-010-0685-2

Mel'nik, V.A. 2011. Anamorphic fungi of Vietnam. I. - Mikologiya i Fitopatologiya 45: 323-331. (In Russian)

Mel'nik, V.A. 2012a. A new species of Ardhachandra (hyphomycetes) from Vietnam. - Mycosphere 3: 922-924.

Mel'nik, V.A. 2012b. Phaeoisariopsis vietnamensis sp. nov. and P. clematidis (hyphomycetes) from Vietnam. - Mycosphere 3: 957-960.

Mel'nik, V.A., Novozhilov, Yu.K., Popov, E.S. \& Alexandrova, A.V. 2012. Anamorphic fungi of Vietnam. II. - Mikologiya i Fitopatologiya 46: 347-356. (In Russian)

Mel'nik, V.A., Braun, U. \& Alexandrova, A.V. 2013. Dactylaria mucoglobifera sp. nov. - a new species from Vietnam. - Schlechtendalia 25: 49-52.

Mercado, S.A. \& Mena, P.J. 1988. Nuevos o raros hifomicetes de Cuba. - Acta Botanica Cubana 59: 1-6. 
Seifert, K., Morgan-Jones, G., Gams, W. \& Kendrick, B. 2011. The genera of Hyphomycetes. - CBS Biodiversity Series 9: 1-997.

Shenoy, B.D., Jeewon, R., Wu, W.P., Bhat, D.J. \& Hyde, K.D. 2006. Ribosomal and RPB2 sequence analyses suggest that Sporidesmium and morphologically similar genera are polyphyletic. - Mycological Research 110: 916-929. http://dx.doi.org/10.1016/j.mycres.2006.06.004

Subramanian, C.V. 1992. A reassessment of Sporidesmium (Hyphales) and some related taxa. - Proceedings of the Indian National Sciences Academy 58: 179-190.

Wu, W.P. \& Zhuang, W.Y. 2005. Sporidesmium, Endophragmiella and related genera from China. - Fungal Diversity Research Series 15: 1-351.

Zhang, Y.D., Ma, J., Ma, L.G., Castañeda, R.F. \& Zhang, X.G. 2011. New species of Phaeodactylidium and Neosporidesmium from China. - Sydowia 63: 125-130. 